\title{
TRANSPORT INFRASTRUCTURE ROLE IN CLIMATE RESILIENCE: A CASE STUDY IN HUNGARY
}

\author{
Adam Torok ${ }^{1}$ \\ ${ }^{1}$ Budapest University of Technology and Economics, Department of Transport Technology and \\ Economics, Sztoczek u.2. Budapest, Hungary
}

Received 21 September 2015; accepted 19 May 2016

\begin{abstract}
Climate change is very important and plays a significant role. First solution against it could be the mitigation in order to reduce the global environmental impact of climate change, which can only work effectively over long-time. Second option is adaptation. These solution can be distinguished in transport as well. In the future in Hungary the probability, the frequency and the caused damage of extreme weather condition will increase in-line with that the adverse economic, environmental and ecological impacts will worsen. The environmental damage will cause social and economic problems such as damaged infrastructure - not only road and railway, but author focusing on them in this paper -, pause in social services (hospital, public transport). The disasters seriously affect the transport and with that a significant proportion of the domestic population. The aim of this article is to analyse the connection between the spatial distribution of transport infrastructure and vulnerable areas. The targeted research question if transport infrastructure would enlarge or help avoiding the effects of climate change.
\end{abstract}

Keywords: transport infrastructure, climate change, vulnerability, resilience.

\section{Introduction}

In spite of the fact that Hungary is one of the most endangered countries by climate change in Europe considering many aspects and the annual increase of average temperature is one and a half times faster than the global average, Hungarians are less afraid of climate change than an average citizen of the European Union. Climate change affects ecosystems, transportation, forests, agriculture, water management and human health (VadadiFülöp and Hufnagel, 2014; Mitsakis et al., 2014a). The environmental effects of temperature change cause ecological damages as well as significantly influence the existence of different species. The most important change is the significant rise in mainland temperature and the somewhat more moderate growth in the temperature of oceans (Mitsakis et al., 2014b). The 1990 s was the warmest decade of the past millennium. Projections show that we can expect local temperature swings across the entire globe. We also need to reckon with warmer summers in many parts of Europe. There are already fewer observed frost days. Significant changes in the distribution of precipitation are also likely to occur, and this will result in prolonged periods of droughts, as well as rains causing intense floods and dry periods. The frequency of summer droughts has already manifestly increased. The changes in the distribution of precipitation could result in the desertification of certain regions, and may also significantly decrease

${ }^{1}$ Corresponding author: atorok@kgazd.bme.hu 
groundwater levels in numerous areas (Nagy Bíró and Boros, 2011; Sallay et al., 2012). Higher temperatures lead to greater evaporation in the oceans, but at the same time the increased vapours will also lead to more precipitation. The water cycle is becoming more intense, and in substantial portions of the northern hemisphere precipitation levels have grown by $5-10 \%$ (Bartholy and Gelybó, 2007).

\section{Methodology - Statistical Analysis of Local Weather Extremities}

Temperature data has been collected from Hungarian Measurement Network (100 measurement point). These data points provide long-time series of 10 minutes sample time. Precipitation has been collected in 600 points. The analysis of collected data has been done within the 1981-2010 time period. The measured data has been stored in a Geographical Information System with the resolution of $0.1^{\circ}$. The interpolation of measured data has been done by splinemethod. The problem was that the geostatistical methods were unable to solve the computation of long-time series. Therefore new Meteorological Interpolation based on Surface Homogenized Data Basis were developed and used. Two different statistical methods were used in interpolation: the additive interpolation method where the error of interpolation is minimal and the multiplicative interpolation method where the local parameters can be estimated. Therefore the optimal interpolation parameters depend only on local estimated parameters and cross-correlation of other long-time series. After that the analysis of extreme values (temperature, wind and precipitation) was done. According to the international literature statistical experience state that independently from the distribution of the sample the extreme values have a Jenkinson - von Mises distribution (General Extreme Value Distribution). This is only valid for maximal extremes. For minimal extremes - in climatology Gumbel distribution is found as correct (Gyenes, 2011).

The statistical description of climate models has been upgraded by the author with the main transport infrastructure elements. Infrastructure plays and important role in resilience in NUTS 4 level. Climate resilience can be understand as the capacity for a socio-ecological system to maintain its original function in the face of external stresses caused by climate change or extreme weather condition. Further on it needs to adapt, reorganize, and evolve into more desirable configurations that improve the sustainability of the system. Unfortunate fact that a few serious natural disaster events have already happened in Hungary entailing significant social, ecologic, economic and physical impacts where transport infrastructure played a significant role. Rapid response mitigation actions and long term analysis of these events have both already been conducted and showed that transport infrastructure played a unique role because well managed infrastructure could lowered the exposure of the territory, however, it is needed to mention that infrastructure itself can be critical infrastructure which increases the risk of vulnerability. In this article risk is compounded from the probability and effect of the extreme weather condition. From the above a well-known risk-matric (Table 1) can be concluded (Schneller et al., 2013). 


\section{Table 1}

Categories of Disaster Management

\begin{tabular}{|l|l|l|l|l|}
\hline \multirow{2}{*}{ Effect } & Probability & Not often & Often & Very Often \\
\cline { 2 - 5 } & Rare & middle & high & high \\
\hline Very Serious & middle & middle & middle & high \\
\hline Serious & low & low & middle & middle \\
\hline Not serious & low & low & low & low \\
\hline Low & low &
\end{tabular}

Source: Pálvölgyi and Szendrő (2012)

\section{Results}

Climate change simulation results were considered based on the resilience of transport infrastructure. Transport infrastructure plays an important role in ranking vulnerability as transportation itself plays a significant role in the society. Wind speed over 90 or $120 \mathrm{~km} / \mathrm{h}$ can cause significant transport problems (Fig. 1a and 1b) such as closed infrastructure links due to fallen trunk, or the electric transmission system can be damaged as well that influences public services.

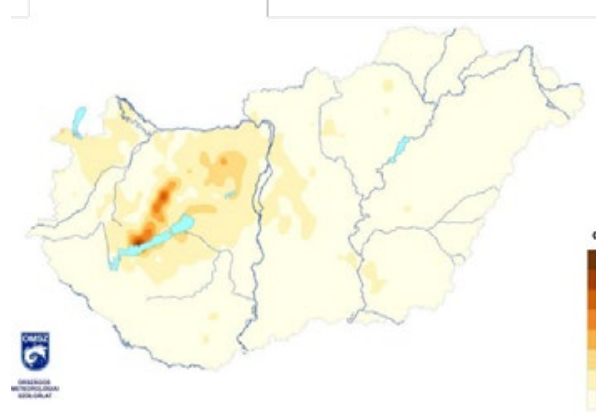

(a)

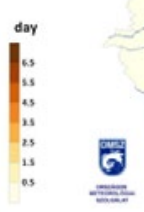

Fig. 1.

Source: Gyenes (2011)

Based on the investigation between 19812010 it can be stated that the $90 \mathrm{~km} / \mathrm{h}$ wind maximums are likely to be at Kisalföld, Dunántúli-középhegység, and Balaton. The 120 $\mathrm{km} / \mathrm{h}$ wind maximums with the greatest probability according to the investigation are at Dunántúli-középhegység.
Extreme hot is a maximum daily average temperature exceeds $27^{\circ} \mathrm{C}$ for more than 3 days by definition (Fig. $2 \mathrm{a}$ and $2 \mathrm{~b}$ ). It causes increased mortality rate, lower concentration rate of drivers, increased checking of infrastructures (bridges, tracks). 


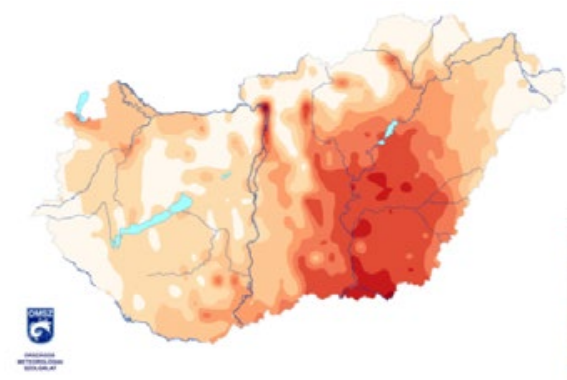

(a)

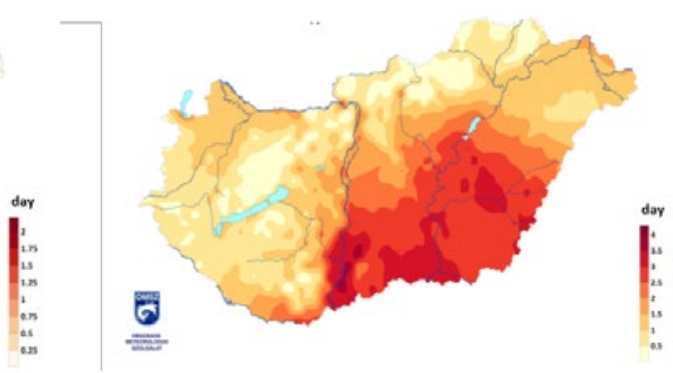

(b)

Fig. 2.

Yearly Average Appearance of Daily Maximum $27^{\circ} \mathrm{C}$ and $35^{\circ} \mathrm{C}$ Air Temperature Source: Gyenes (2011)

The analysis of maximum temperature shows that the most sensitive areas are Alföld, within that Duna-Tisza köze and south part of Tiszántúl. Huge rain is $50 \mathrm{~mm}$ more precipitation within 24 hours by definition (Fig. 3). It causes floods, transport problems of missing infrastructure links, traffic controlling break down, slower speed, sewer system become full, the service level is damaged (public services, infrastructure).

\section{Fig. 3.}

Yearly Average Appearance of $50 \mathrm{~mm}$ or More Precipitation

Source: Gyenes (2011)

The investigation of precipitation shows that as Északi-középhegység, Dunántúli-középhegység, the most influenced places are the hills such Mecsek and Alpokalja. 


\section{Analysis and Discussion}

Vulnerability of a system refers to its physical, social, and economic aspects. According to IPCC, vulnerability is a function of the character, magnitude and rate of climate variation to which a system is exposed; its sensitivity; and adaptive capacity. Based on this the following extreme situations were considered and characterised (Fig. 4):

Fig. 4.

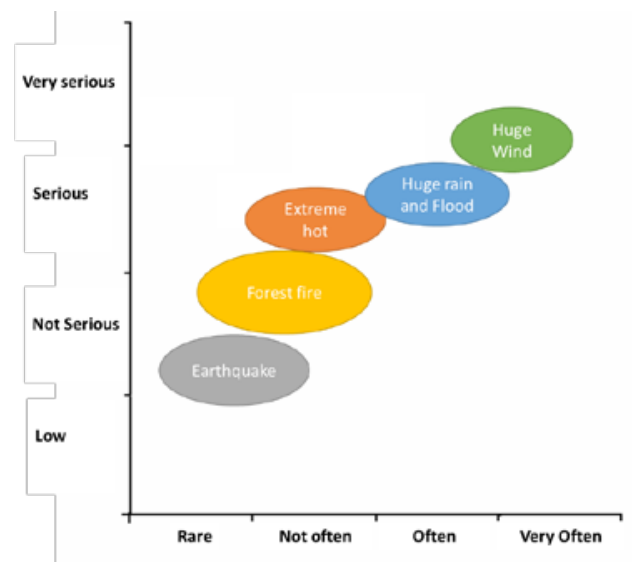

Catastrophes and Extreme Weather Conditions in Hungary

Source: Gyenes (2011)

From the above definition, we can note that IPCC uses three terms to define vulnerability as exposure, sensitivity and adaptive capacity. Exposure can be defined as degree of climate stress upon a particular unit analysis; it may be represented as either long-term changes in climate conditions, or by changes in climate variability, including the magnitude and frequency of extreme events. In this case it is considered as change in temperature and precipitation (Fig. 5).

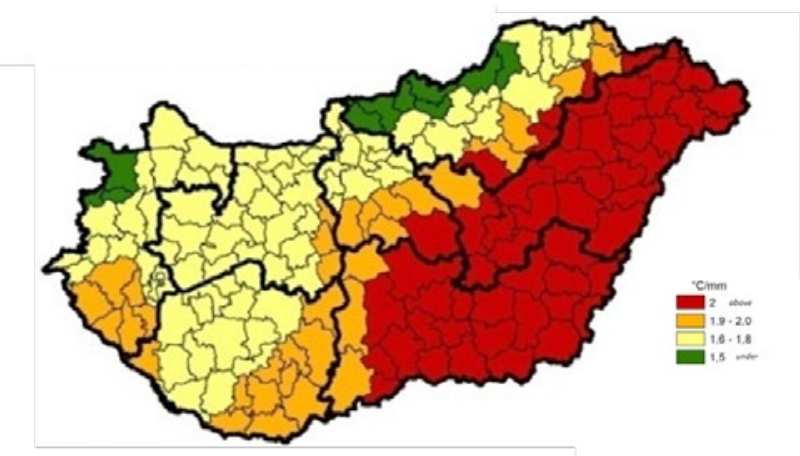

Fig. 5.

Exposure

Source: Pálvölgyi et al. (2010) 
Sensitivity is the degree to which a system biophysical effect of climate change. For will be affected by, or responsive to example in our case draught was considered climate stimuli. Sensitivity is basically the (Fig. 6).

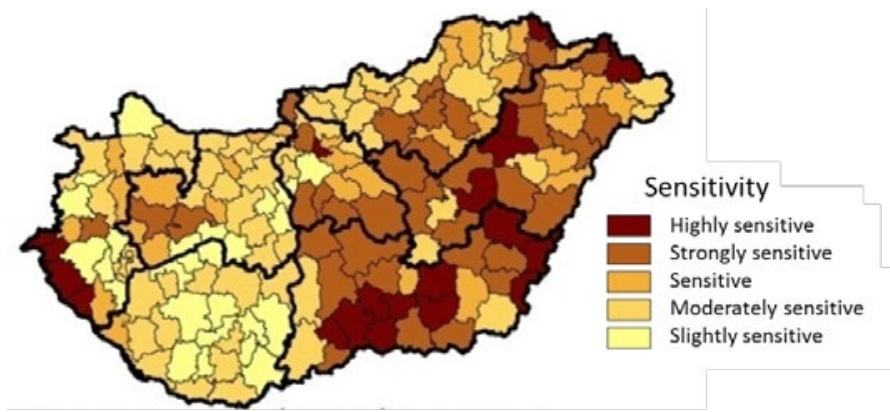

Fig. 6.

Draught Sensitivity

Source: Pálvölgyi et al. (2010)

Adaptive capacity refers to the potential or capability of a system to adjust to climate change, including climate variability and extremes, so as to moderate potential damages, to take advantage of opportunities or to cope with consequences (Csete et al., 2010; Szendrö et al., 2014). As the name suggests, adaptive capacity is the capability of a system to adapt to impacts of climate change (Fig. 7).

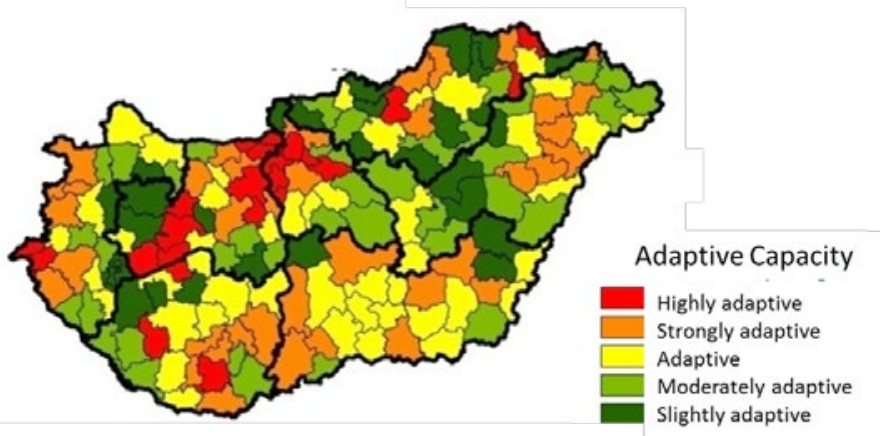

Fig. 7.

Adaptive Capacity

Source: Pálvölgyi et al. (2010)

The 3 pillars can be merged together as vulnerability by definition (Csete et al., 2013) and has been visualized (Fig. 8): 


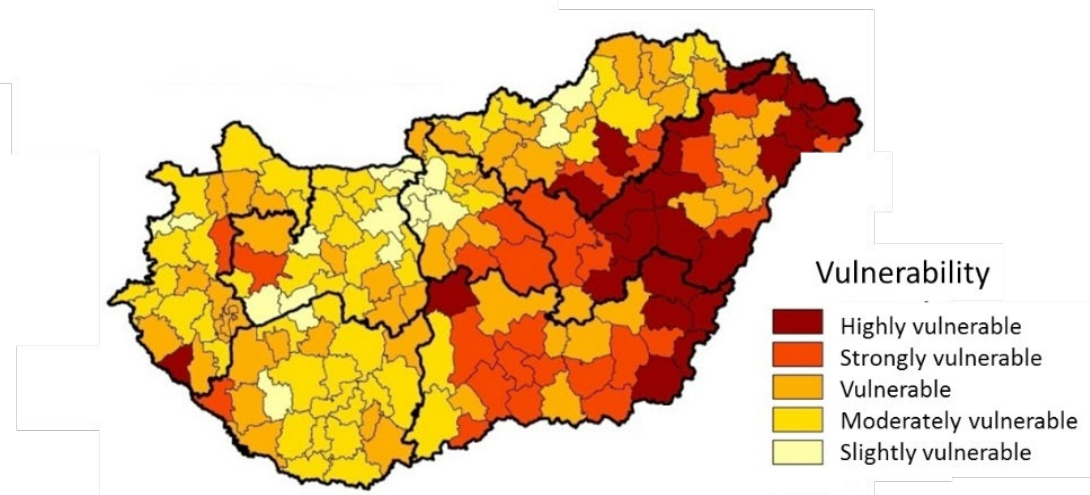

Fig. 8.

Vulnerability

Source: Pálvölgyi et al. (2010)

The vulnerability can be combined with the maps of transport infrastructure in Hungary in order to emphasize the role of transport infrastructure in vulnerability and in hazard

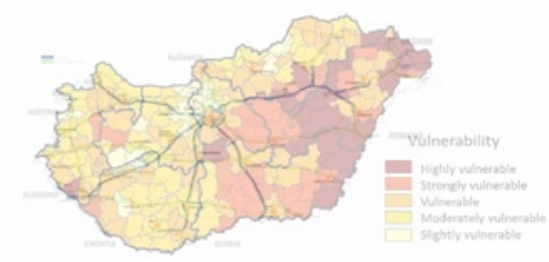

(a)

Fig. 9.

Vulnerability of Motorway System

As for conclusion it can be stated that M3, E60 and M5 motorway goes on the highly vulnerable regions therefore they are critical infrastructure elements. A clear and comprehensive picture of affected regions and various transport infrastructures can be found. When these infrastructures are management and operative management of hazard consequences. Therefore the connection between vulnerability and spatial distribution of infrastructures was visualised:

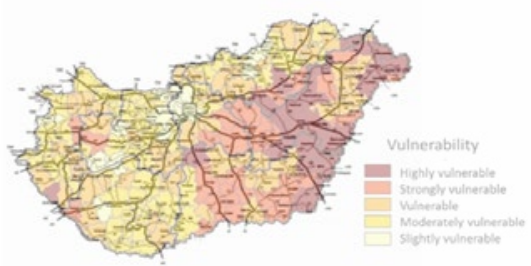

(b) well managed they can serve the society and lower the climate vulnerability of the region. As climate change has an impact on wide range: from geologic to social demography therefore the transboundary effects of badly managed critical infrastructures can have incredible effects on regional vulnerability. 


\section{Acknowledgement}

This paper was supported by the János Bolyai Research Scholarship of the Hungarian Academy of Sciences. Author is grateful for the support of Maria Csete, head of department of Environmental Economics and Regional Sciences at BME. Further on author is thankful for the support of National Adaptation Centre of Geological and Geophysical Institute of Hungary.

\section{Reference}

Bartholy, J.; Gelybó, R.P.-G. 2007. Regional Climate Change Expected in Hungary for, Applied Ecology and Environmental Research, 5(1): 1-17.

Csete, M.; Pálvölgyi, T.; Szendrő, G. 2013. Assessment of climate change vulnerability of tourism in Hungary, Regional Environmental Change, 13(5): 1043-1057.

Csete, M.; Wickens, E.; Soteriades, M. 2010. Microregional analysis of sustainability related to the adaptive capacity of tourism in Tisza Region, Hungary, eds, 280-290.

Gyenes, Z. 2011. National Disaster Risk Assessment (in Hungarian: Nemzeti Katasztrófa Kockázati Értékelés), Budapest, Hungary: Ministry of Interal Affairs (in Hungarian: Belügyminisztérium).

Mitsakis, E.; Papanikolaou, A.; Ayfadopoulou, G.; Salanova, J.; Doll, C.; Giannopoulos, G.; Zerefos, C. 2014a. An integrated framework for linking climate change impacts to emergency adaptation strategies for transport networks, European Transport Research Review, 6(2): 103-111.

Mitsakis, E.; Stamos, I.; Diakakis, M.; Salanova Grau, J.M. 2014b. Impacts of high-intensity storms on urban transportation: applying traffic flow control methodologies for quantifying the effects, International Journal of Environmental Science and Technology, 11(8): 2145-2154.
Nagy Bíró, A.; Boros, T. 2011. Climate Change Policy in Hungary, Budapest: Friedrich Ebert Stiftung Büro Budapest.

Pálvölgyi, T.; Czira, T.; Dobozi, E.; Rideg, A.; Schneller, K. 2010. The method and results of climate change vulnerability assessment on the sub-regional level (in Hungarian: A kistérségi szintű éghajlatváltozási sérülékenység vizsgálat módszere és eredményei), Klíma 21, 62: 88-101.

Pálvölgyi, T.; Szendrő, G. 2012. Trends and indicators for sustainable mobility in Hungary, Acta Oeconomica, 1: 125-132.

Sallay, A.; Jombach, S.; Filepné Kovacs, K. 2012. Landscape Changes and Function Lost Landscape Values, Applied Ecology and Environmental Research, 10(2): 157-172.

Schneller, K.; Bálint, G.; Chicos, A.; Csete, M.; Dzurdzenik, J.; Göncz, A.; Petrisor, A.-I.; Jaroslav, T.; Pálvögyi, T.; Schmidt-Thome, P. et al. 2013. Climate change impacts on the Hungarian, Romanian and Slovak Territories of the Tisza catchment area. In European Climate Vulnerabilities and Adaptation, P. Schmidt-Thome, and S. Greiving, eds. (Oxford: Wiley-Blackwell Publishing Ltd.), 205-230.

Szendrő, G.; Csete, M.; Török, Á. 2014. The Sectoral Adaptive Capacity Index of Hungarian Road Transport, Periodica Polytechnica Social and Management Sciences, 22(2): 99-106.

Vadadi-Fülöp, C.; Hufnagel, L. 2014. Climate change and plankton phenology in freshwater: current trends and future commitments, Journal of Limnology, 73(1): 1-16. 